\title{
Effective Degradation of 2,4,6-Trinitrotoluene (TNT) with a Bacterial Consortium Developed from High TNT-degrading Bacteria Isolated from TNT-contaminated Soil
}

\author{
2,4,6-Trinitrotoluen (TNT) ile Kirlenmiş Topraktan İzole \\ Edilen TNT'yi Parçayalan Bakterilerden Oluşan Bir Bakteri \\ Konsorsiyumu ile TNT'nin Etkili Parçalanması \\ Research Article
}

Zehra Gün Gök1, Murat İnal2*, Mustafa Yiğitoğlu²

'Department of Bioengineering, Institute of Science, Hacettepe University, Ankara, Turkey.

${ }^{2}$ Department of Bioengineering, Faculty of Engineering, Kırıkkale University, Kırıkkale, Turkey.

\section{A B S TR AC T}

\begin{abstract}
n this study, bacterial strains, capable of using TNT as a nitrogen source, were isolated from TNT-contaminated soil samples collected from military region in Kırıkkale, Turkey. We selected three strains that showed the highest TNT degradation capacity and according to $16 \mathrm{~S}$ rRNA sequence analysis, the strains were identified as Klebsiella pneumoniae (designated SC1 K1, showed 99\% homology), Raoultella planticola (designated SC1 K4, showed 99\% homology) and Pseudomonas putida (designated SC1 K5, showed 99\% homology). These strain were cultured in medium containing $100 \mathrm{mg} \mathrm{L}^{-1} \mathrm{TNT}, \mathrm{SC} 1 \mathrm{~K} 1$ degraded $90 \%$ of the initial TNT, SC1 K4 degraded $95 \%$ of the initial TNT, and SC1 K5 degraded $84 \%$ of the initial TNT after $24 \mathrm{~h}$ of incubation. Then, to remove TNT more efficiently, we constructed a bacterial consortium with these strains. The developed consortium was cultured in medium containing $100 \mathrm{mg} \mathrm{L}^{-1} \mathrm{TNT}$ and the consortium removed $97.2 \%$ of the initial TNT after four-hour incubation period. According to HPLC analyses, The consortium transformed TNT to 2-amino-4,6dinitrotoluene, 4-amino-2,6-dinitrotoluene and an unknown metabolite. The isolates showed high TNT degradation capacity compared to many previous studies and the developed bacterial consortium can be used to remediate the TNT-contaminated environments.
\end{abstract}

Key Words

2,4,6-trinitrotoluene, bacterial consortium, biodegradation, bioremediation.

öz

$\mathrm{B}$ u çalışmada, Kırıkkale'de askeri bölgeden alınan TNT ile kontamine toprak örneklerinden, TNT'yi azot kaynağı olarak kullanabilen bakteri suşları izole edilmiştir. En yüksek TNT parçalama kapasitesi gösteren üç suş seçilmiş ve 16S rRNA dizi analizine göre suşlar Klebsiella pneumoniae (SC1 K1 olarak gösterildi,\% 99 homoloji gösterdi), Raoultella planticola (SC1 K4 olarak gösterildi,\% 99 homoloji gösterdi) ve Pseudomonas putida (SC1 K5 olarak gösterildi,\% 99 homolog gösterdi) olarak tanımlanmıştır. Bu suşlar 100 mg L-1 TNT içeren besiyerinde kültür edilmiş ve 24 saatlik inkübasyon süresinin sonunda SC1 suşu başlangıçtaki TNT'nin \% 90'ını, SC1 K4 suşu başlangıçtaki TNT'nin \% 95'ini ve SC1 K5 suşu başlangıçtaki TNT'nin \% 84'ünü parçalamıştır. Ardından, TNT'yi daha etkili parçalamak için bu suşlarla bir bakteri konsorsiyumu oluşturulmuştur. Geliştirilen konsorsiyum 100 $\mathrm{mg} \mathrm{L}^{-1}$ TNT içeren besiyerinde kültür edilmiş ve 4 saatlik inkübasyon süresinden sonra konsorsiyum başlangıçtaki TNT'nin \% 97,2'sini yok etmiştir. HPLC analizlerine göre, konsorsiyum TNT'yi 2-amino-4,6-dinitrotoluen, 4-amino-2,6-dinitrotoluen ve bilinmeyen bir metabolite dönüştürmüştür. İzolatlar önceki birçok araştırmaya kıyasla yüksek TNT parçalama kapasitesi göstermiş ve oluşturulan bakteriyel konsorsiyum TNT ile kontamine olmuş ortamların remediasyonunda kullanılabilir.

\section{Anahtar Kelimeler}

2,4,6-trinitrotoluen, bakteri konsorsiyumu, biyolojik parçalanma, biyoremediasyon .

Article History: Received: Feb 19, 2018; Revised: Mar 5, 2018; Accepted: Jul 6, 2018; Available Online: Oct 4, 2018.

Dol: $10.15671 /$ HJBC.2018.252

Correspondence to: M. İnal, Department of Bioengineering, Faculty of Engineering, Kırıkkale University, Kırıkkale, Turkey. 


\section{INTRODUCTION}

A II around the world, in the last 150 years, millions tones of nitroaromatic compounds have been manufactured for military purposes and activities [1]. Production, utilization, and discarding activities of these compounds at ammunition production sites have caused wide contamination of soil and groundwater [26]. 2,4,6-trinitrotoluene (TNT) is known as the worst one among these pollutants because of its environmental stability formed by the nitro groups having symmetric locations in the structure of TNT $[3,5,6]$.

TNT is the most extensively used explosive compound for military and other applications because of its low melting point, thermal and chemical stability, its low sensitivity toward impact, high temperature, and friction [7-11]. Although TNT is extensively used for military application since discovered of its explosive potential in 1902, it is a toxic agent and also has mutagenic impacts on different organisms including human [12-15]. It is designated as a possible human carcinogenic substance (class C) by United States Environmental Protection Agency. Occupational and incidental exposures to TNT result in rashes, skin irritation, blood, mucus, and immune disorders $[16,17]$. Toxic effects of TNT including disturbance of liver function and anemia have been stated by workers in the large scale manufacturing plants $[15,18]$. Based on all these points, treatment of TNT contaminated sites is significant to assure human health and natural ecosystems.

Several processes have been recommended for the treatment of TNT contaminated soil and water including incineration, composting, chemical reduction, adsorption, thermal decomposition, subcritical water degradation and photocatalytic degradation $[5,8,19]$. Each of these processes has its own restrictions and is a very expensive methods $[8,17,20]$. Among these processes, incineration is the most efficiently and extensively used process, but the use of this process for cleaning the contaminated sites is high cost due to the prices of soil digging, transporting and energy required for incineration of soil $[5,8,21]$. Composting is also inefficient since it requires many compost materials mixed with wastes $[8,22]$. In chemical oxidation, it is often difficult to treat of explosive materials because it needs to contain unreacted materials $[8,22]$. Carbon adsorption is frequently used for treatment of nitroaromatic compounds from contaminated water but the matrix used in this process is expensive and also the spent carbon produces a problematic waste $[20,23,24]$. Therefore, recent studies have mostly focused on bioremediation for removal of TNT because bioremediation of contaminated environment is more economical and also less environmental damage [25-27].

All over the world, the degradation of TNT by fungi $[28,29]$, plants [30], anaerobic bacteria, [31,32] and aerobic bacteria [33] has been extensively studied for many years. Most studies focus mainly on finding microorganisms that are required for making efficient techniques for bioremediation of sites contaminated with TNT [1]. Fungi are resistant to high concentrations of nitroaromatic compounds but the harsh environmental conditions such as temperature affect the survival of them [34]. Another disadvantage of using fungi for TNT degradation is that some fungi are indigenous to wood instead of soil and they may not compete with soil fungi when they used for bioremediation of TNT-contaminated soil [5,35]. The plants, which are genetically modified, can be used for the bioremediation of nitroaromatics. However, the usage of transgenic plants is not favorable due to ethical and environmental problems associated with genetically modified plants [30]. Moreover, plants used for cleaning of contaminated areas degrade TNT and they immobilize it by adding into cell walls and vacuoles. That situation leads to the formation of plants contaminated with TNT [7]. Biodegradation of TNT under anoxic environment has become an alternative approach to remediation [32] and anaerobic microbial degradation of TNT provides complete mineralization of the contaminants [20], but harsh anaerobic conditions are required for this process [16]. Due to high TNT degradation rates, the relatively low cost and simple techniques, biodegradation of TNT by aerobic bacteria is currently promising option [34,36]. In the literature, many studies have reported bacterial 
degradation of TNT with pure isolates; however, TNT mineralization or biotransformation to intermediates by pure bacterial cultures are fairly rare. Usually, mineralization takes place with a bacterial consortia [37].

The purpose of this study is to construct a bacterial consortium from TNT-degrading microorganisms isolated from TNT-contaminated soil to degrade and mineralize TNT with high efficiency. TNT-degrading microorganisms were isolated from TNT-contaminated sites in Kırıkkale, Turkey and TNT contamination levels of the collected samples were determined. The sites where samples were collected for isolation of bacteria were used for military applications for years. However, there has been no study on isolation of TNT-metabolizing microorganisms from these sites or quantification of TNTcontamination levels in wastewater and soil samples in that TNT-contaminated environment. We isolated 19 bacterial strains from collected soil samples and among the isolated bacteria, three strains showed high TNT degradation capacity. Then, we developed a bacterial consortium from the selected three strains and we investigated TNT degradation with consortium and analyzed degradation metabolites with HPLC.

\section{MATERIALS and METHODS \\ Collection of Soil Samples and Analysis}

For the isolation of TNT degrading microorganisms soil samples were taken from TNT- contaminated sites in Kırıkkale, Turkey. Soil samples were taken from depths of pink water and around the pink water with a depth of $5-10 \mathrm{~cm}$. The amounts of TNT in collected samples were determined by a spectrophotometer at $530 \mathrm{~nm}$ based on the method previously reported by Üzer et al. [38] with some modifications. TNT amounts of soil samples were determined to be between 49-346 $\mathrm{mg} / \mathrm{kg}$.

\section{Culture Conditions and Chemicals}

The analytical

2,6-dinitrotoluene

2,4-dinitrotoluene (2,4-DNT) were purchased from Fluka (USA). 2-amino-4,6-dinitrotoluene (2-ADNT) and 4-amino-2,6-dinitrotoluene (4ADNT) standards were purchased from Cerilliant
(USA). TNT was taken from The Machinery and Chemical Industry Institution (Kırıkkale, Turkey). HPLC-grade methanol and other chemicals used had the highest analytical grade and were all obtained from Sigma-Aldrich. For all experiments, the degradation capacity of the isolates and the bacterial consortium were assayed in liquid basal salts medium consisted of (grams per liter) $\mathrm{Na}_{2} \mathrm{HPO}_{4}, 6 ; \mathrm{KH}_{2} \mathrm{PO}_{4}, 3 ; \mathrm{NaCl}, 0.5 ; \mathrm{MgSO}_{4}$, 0.24; glucose 10 and TNT 0.1. After addition of all components, the basal salts medium was sterilized with autoclave at $121^{\circ} \mathrm{C}$ for $15 \mathrm{~min}$. In all experiment, the strains were incubated overnight with a constant shaking at $120 \mathrm{rpm}$ in aerobic condition. The growth of bacteria was followed by turbidity measurements at $600 \mathrm{~nm}$ wavelengths using Libra S70 UV/Vis Spectrometer (Biochrom, UK). The nutrient agar (composed of $\mathrm{g} \mathrm{L}^{-1}$; peptone, 5; $\mathrm{NaCl}, 5$; yeast extract, 3; agar agar, 15) was used to store the isolated strains at +4 ${ }^{\circ} \mathrm{C}$ and the nutrient broth (composed of $\mathrm{g} \mathrm{L}^{-1}$; peptone, $5 ; \mathrm{NaCl}, 5$; yeast extract, 3 ) was used to culture the bacterial cells before inoculation to the degradation medium. All experiments were repeated three times, non-inoculating sterilized medium was used as the control group and the data were plotted as means with standard deviations.

\section{Isolation and Identification of the Microorganisms}

A selective enrichment procedure using TNT as sole nitrogen was used to isolate bacterial strains from TNT-contaminated soil. A 1-gram soil sample was homogenized with $9 \mathrm{~mL}$ sterile water, then the suspension was well mixed and allowed to settle down. $1 \mathrm{~mL}$ sample withdrawn from the supernatant was inoculated to $100 \mathrm{~mL}$ degradation medium containing 100 ppm TNT as sole nitrogen source and then the flasks were incubated at $30^{\circ} \mathrm{C}$ with constant shaking at 120 $\mathrm{rpm}$ in aerobic condition. The inoculants were transferred to fresh degradation medium after 3 days of incubation. The resultant bacterial cultures were streaked on nutrient agar plates and incubated overnight at $30{ }^{\circ} \mathrm{C}$ after 1 day of incubation. Following incubation, separated and morphologically different colonies were selected and individually isolated. Totally 19 bacterial strains were isolated from TNT-contaminated soil 
samples. The purified isolates were characterized by Gram staining [39] and the 16S rRNA sequence analysis. The 16S rRNA sequence analyses were performed in Gazi University Life Sciences Research and Application Centre, Ankara, Turkey. By using UNI27F/1492R primer pairs, 16S rRNA gene sequences of the isolates were amplified by PCR and sequenced with the same primer pairs. The sequences were analyzed with results of the NCBI (National Center for Biotechnology Information) Blast database (htpp://blast.ncbi. nIm.nih.gov/Blast.cgi) to search 16S rRNA similar sequences with the isolates.

\section{Determination TNT Degradation Rate of the Isolates}

The degradation abilities of the isolates were assayed in liquid basal salts medium containing TNT as sole nitrogen source. For three strains, before inoculation to the basal salts medium, a pure single colony was selected and cultured overnight in nutrient broth at $30{ }^{\circ} \mathrm{C}$ and 120 $\mathrm{rpm}$ to attain exponential phase (absorbance at $600 \mathrm{~nm} \sim 1.5$ ). The cultured bacterial cells in nutrient broth were used as an inoculum at $2 \%$ $(\mathrm{v} / \mathrm{v})$ to the basal salts medium to assay bacterial degradation capacity of the isolates. The cultures in $250 \mathrm{~mL}$ flasks were incubated at $30^{\circ} \mathrm{C}$ at 120 rpm for overnight. The bacterial growth of the cultures was determined by measuring the optical density at $600 \mathrm{~nm}$. After incubation, at regular intervals (every $4 \mathrm{~h}$ ), aliquots were collected from the cultures to monitor TNT amount and then the cells removed by centrifugation at $10000 \mathrm{xg}$ for 15 minutes. To $5 \mathrm{~mL}$ of the supernatant, $1 \mathrm{~mL} 1 \mathrm{M} \mathrm{KOH}$ was added and mixed, the amount of TNT in the solution was found out by measuring absorbance at $447 \mathrm{~nm} 5 \mathrm{~min}$ after addition of $\mathrm{KOH}$ solution to the supernatant of the culture of isolates $[13,40]$.

\section{Construction of Bacterial Consortium and TNT Degradation}

The bacterial consortium was developed according to Shanmugam and Mahadevan [41]. A pure single colony of all the three bacteria was selected and cultured separately in nutrient broth, and incubated overnight at $30^{\circ} \mathrm{C}(120 \mathrm{rpm})$ to obtain exponential phase (OD 600 1.5). $2 \%$ (v/v) inoculum from each bacterial species was used to inoculate $100 \mathrm{~mL}$ of basal salts medium in $250 \mathrm{~mL}$ vessels. The developed bacterial consortium was cultivated at $30^{\circ} \mathrm{C}$ at $120 \mathrm{rpm}$ for overnight. The bacterial growth was followed by optical density measurement at $600 \mathrm{~nm}$. After incubation, the amount of TNT in the culture of the consortium was determined by spectrophotometric analysis as described above and HPLC analysis as described below.

\section{Determination of Biotransformation Metabolites}

During the TNT degradation experiments with the bacterial consortium, the degradation metabolites of TNT were analyzed by HPLC. The samples were prepared by mixing $1.5 \mathrm{~mL}$ of culture supernatants with $3.5 \mathrm{~mL}$ of methanol. The whole mixture was swirled for 5 minutes and then filtered with $0.22 \mu \mathrm{m}$ Millex-GP syringe filter unit (Sigma-Aldrich). Then the filtrate was used for HPLC analysis. $10 \mu \mathrm{L}$ of elution was injected into an Ultra Aromax column (150 mm x $4.6 \mathrm{~mm}, 5$ $\mu \mathrm{m})$ (Restek Corporation, Bellefonte, PA, USA, Cat. Number 9127565 ) at $35^{\circ} \mathrm{C}$ and separated by using an isocratic mobile phase of $30 \%(\mathrm{v} / \mathrm{v})$ deionized water and $70 \%(\mathrm{v} / \mathrm{v})$ methanol at a flow rate $1.2 \mathrm{~mL} / \mathrm{min}$. The retention times of TNT and the transformational metabolites were determined by UV detector at $210 \mathrm{~nm}$ and quantified by making comparison with standards.

\section{Determination of Nitrite and Ammonium}

During growth of microorganisms, to monitor denitration of TNT, release of nitrite and ammonium was determined by using Spectroquant test kits (Merck, Germany). After bacterial cells were inoculated in TNT-containing degradation medium, in every 4 hours, aliquots were withdrawn from culture environment and centrifuged at $10000 \mathrm{xg}$ for 15 minutes. The supernatant was used to determine nitrite and ammonium ions. For nitrite analysis, $5 \mathrm{~mL}$ of supernatant was mixed with one level blue microspoon of Reagent $\mathrm{NO}_{2}-1$ and shaken potently until the reagent was completely dissolved. The $\mathrm{pH}$ of the supernatant was adjusted to 2-2.5 with $1 \mathrm{~N} \mathrm{HCl}$. After 10 minutes, the absorbance of the solution was measured at $525 \mathrm{~nm}$. For ammonium analysis, $0.6 \mathrm{~mL}$ of Reagent $\mathrm{NH}_{4}{ }^{-1}$ and one level blue microspoon of Reagent $\mathrm{NH}_{4}-2$ were added to $5 \mathrm{~mL}$ of supernatant and the solution 
was shaken potently until Reagent $\mathrm{NH}_{4}-2$ was completely dissolved. The mixture was incubated at room temperature for $5 \mathrm{~min}$ and then 4 drops of Reagent $\mathrm{NH}_{4}-3$ were added into the solution. After 5 min, the concentration of ammonium was measured at $690 \mathrm{~nm}$.

\section{RESULTS}

\section{Selection of best TNT degrading}

\section{microorganisms and identification}

19 TNT degrading microorganisms were isolated from TNT-contaminated samples. Between the isolated strains, three isolates having high TNT degradation ability were selected and identified by Gram-staining and 16S rRNA gene sequence analyses. The isolated strains were Gram-negative and rod-shaped bacterium. Based on their 16S ribosomal RNA gene sequence analysis, SC1 K1 showed $100 \%$ homology in the genus Klebsiella SR69 (Gene Bank accession no KF896104.1) and it had 99\% sequence similarity with Klebsiella pneumoniae QLR-1 (Gene Bank accession no KM096433.1). SC1 K4 showed 99\% homology with Raoultella planticola (Gene Bank accession no AF129444.1) and SC1 K5 had $99 \%$ similarities with Pseudomonas putida strain M1 (Gene Bank accession no KP192772.1).

\section{Determination of TNT degradation rate of the isolates}

In order to determine the degradation rate of the isolates, the isolates were incubated in minimal salt medium and the remaining amount of TNT in culture media and bacterial growth were monitored. According to results of the analysis, we found that $\mathrm{SC} 1 \mathrm{~K} 1$ isolate degraded $90 \%$ of the initial TNT and $\mathrm{SC} 1 \mathrm{~K} 4$ degraded $95 \%$ of the initial amount TNT; whereas SC1 K5 removed approximately $84 \%$ of the initial TNT from the degradation medium at $30^{\circ} \mathrm{C}$ by shaking at 120 rpm in aerobic conditions within a 24-h incubation time. Figure 1 showed the remaining amount of TNT in the culture medium of isolates versus bacterial growth during the degradation process. As shown in Figure 1, the remaining amount of TNT in the culture medium decreased as the biomass of the isolates increased.
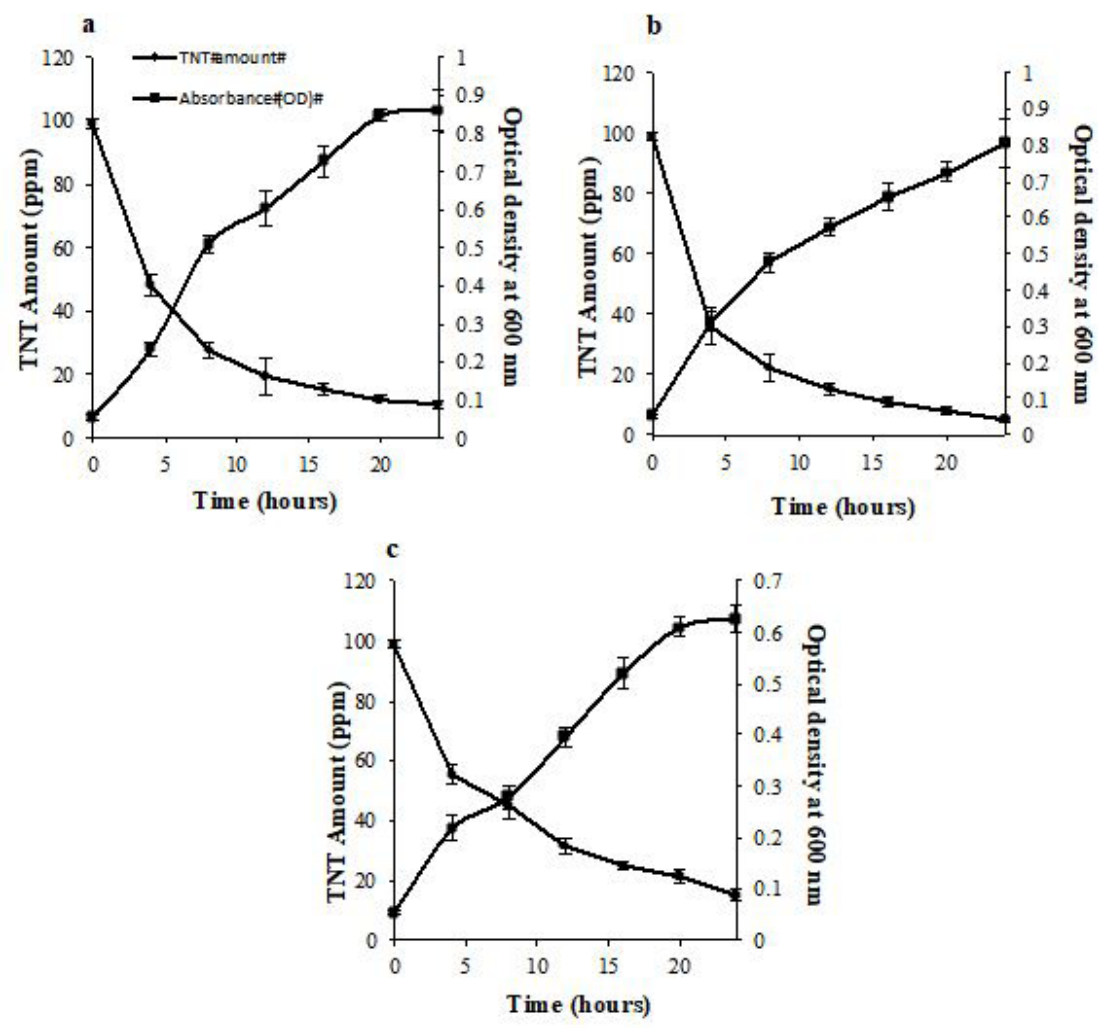

Figure 1. The remaining amounts of TNT in the culture medium of the isolate K. pneumoniae SC1 K1 (a), R. planticola SC1 K4 (b) and P. putida SC1 K5 (c) versus bacterial growth of the isolates. 


\section{TNT degradation with the bacterial consortium}

Isolated and selected strains from soil samples were used to develop a bacterial consortium to degrade TNT. The developed consortium was examined to determine its capacity in removal of TNT. In degradation experiments performed in flasks at an initial concentration of $100 \mathrm{mg} \mathrm{L}^{-1} \mathrm{TNT}$ through HPLC and spectrophotometric analysis, it was determined that the consortium degraded $97.2 \%$ of the initial TNT within 4 hours incubation time. At the end of the 24-hour incubation time, all the initial amount of TNT was removed from the culture medium by the consortium. While the bacteria in the consortium used TNT as a nitrogen source, the bacterial growth increased with time. Figure 2 shows the remaining amounts of TNT in the culture medium of the consortium during the degradation period as well as time-dependent change in turbidity of the consortium.

\section{Determination of Biotransformation Metabolites}

During the degradation study of the consortium, the biotransformation products were identified as 2-ADNT, 4-ADNT, and an unknown metabolite by HPLC. Every four-hour incubation time, the samples were withdrawn from the culture medium used for HPLC analysis and accumulations of 4-ADNT and 2-ADNT in culture medium were detected. The table 1 shows the formation amounts of 2-ADNT and 4-ADNT during the TNT degradation period. As shown in Table 1, the change in 2-ADNT concentration was very small and 2-ADNT amount reached maximum of $1.32 \mathrm{mg} \mathrm{L}^{-1}$ within 8 hours. In contrast to 2-ADNT levels, the accumulation of 4-ADNT was increased with time during the degradation experiments. The amount of 4-ADNT reached maximum of $29.92 \mathrm{mg} \mathrm{L}^{-1}$ within 24 hours. Figure 3 shows the chromatograms of the bacterial consortium at different time interval and the chromatogram of the standards. As shown in Figure 3 , in the culture of the consortium at the beginning of the experiment, there were just TNT peaks with retention time at $22.167 \mathrm{~min}$. At 4-hour incubation time, there were neighboring peaks of 4-ADNT and 2-ADNT with retention times at 5.250 and 6.568 min respectively in the culture of the consortium. At 12-hour incubation time, the TNT peak decreased and at 24 hours incubation time, the TNT peak disappeared. The 2-ADNT and 4-ADNT peaks were observed in 12 and 24 $\mathrm{h}$ and in addition to these compounds; a peak of an unknown metabolite was detected on HPLC chromatograms with retention time at $4.020 \mathrm{~min}$ between 4-24 $\mathrm{h}$. All of these results represented that the isolate transformed TNT to 2-ADNT, 4-ADNT and an unknown metabolite under aerobic condition; whereas, in control group (sterilized medium without inoculation of the bacteria), the TNT was remained and above-mentioned products were not found by the HPLC analysis (data were

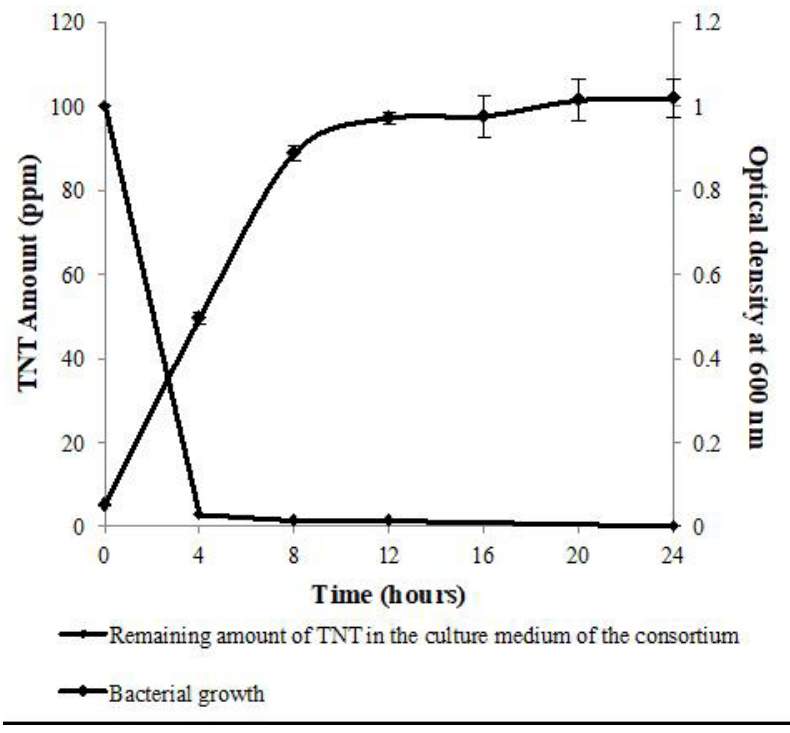

Figure 2. The remaining amounts of TNT versus bacterial growth of the consortium. 
Table 1. Changes of TNT, 2-ADNT and 4-ADNT amounts during the degradation period of the bacterial consortium.

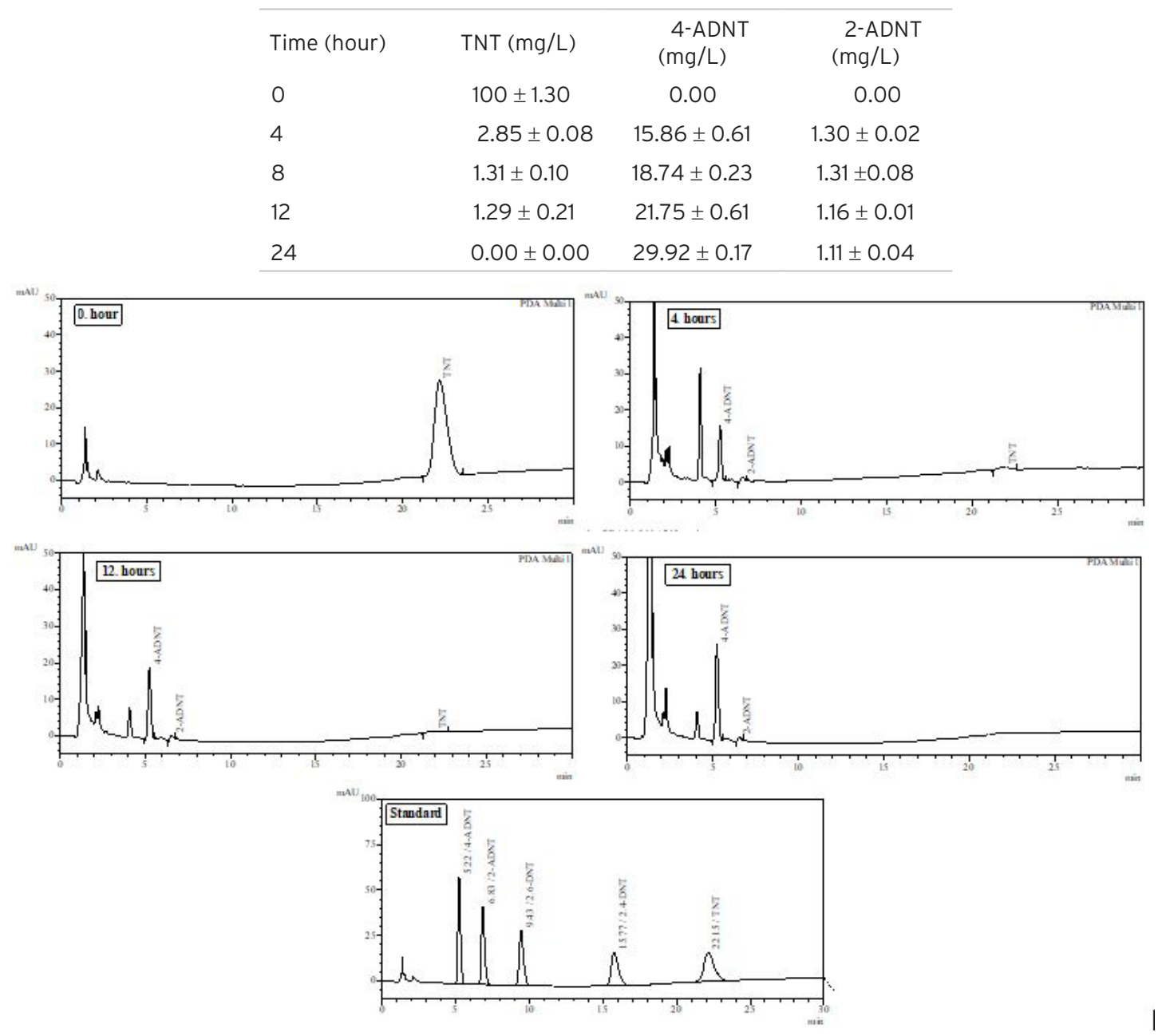

Figure 3. HPLC chromatograms of the bacterial consortium during the degradation period at $\mathrm{O} h$ (top left), at $4 \mathrm{~h}$ (top right), at $12 \mathrm{~h}$ (middle left), at $24 \mathrm{~h}$ (middle right) and standards mixture chromatogram (bottom).

not shown). We used 2,6-DNT, 2,4-DNT, 4-ADNT and 2-ADNT as standards but the accumulation of 2,6-DNT and 2,4-DNT was not observed in the culture of the bacterial consortium.

\section{Release of Nitrite and Ammonium Upon Biodegradation of TNT}

Nitrite and ammonium analyses were done to demonstrate TNT mineralization by the consortium. Figure 4 shows the data of nitrite and ammonium assays during the degradation of TNT. The release of nitrite was detected after 4-hour incubation time and the levels of nitrite ions reached maximum of $0.13 \mathrm{mg} \mathrm{L}^{-1}$ within first hours. Then, the amounts of nitrite levels changed between 0.03-0.05 $\mathrm{mg} \mathrm{L}^{-1}$ during the degradation period. As nitrite levels, ammonium levels were reached a maximum of $0.07 \mathrm{mg} \mathrm{L}^{-1}$ within first hours after incubation and then it changed between 0.03-0.05 $\mathrm{mg} \mathrm{L}^{-1}$.

\section{DISCUSSION}

In this study, from munitions-contaminated sites, we isolated bacterial strains were capable of degrading TNT with high efficiency compared to many previous works [33,40,42-44]. Although $100 \mathrm{mg} \mathrm{L}^{-1}$ TNT concentration is toxic to numerous microorganisms [45], the bacterial cells isolated in this study are capable of growing at this TNT concentration. Since the bacterial strains used in this study were isolated from TNT-contaminated sites, probably, in some degree, the isolates are 


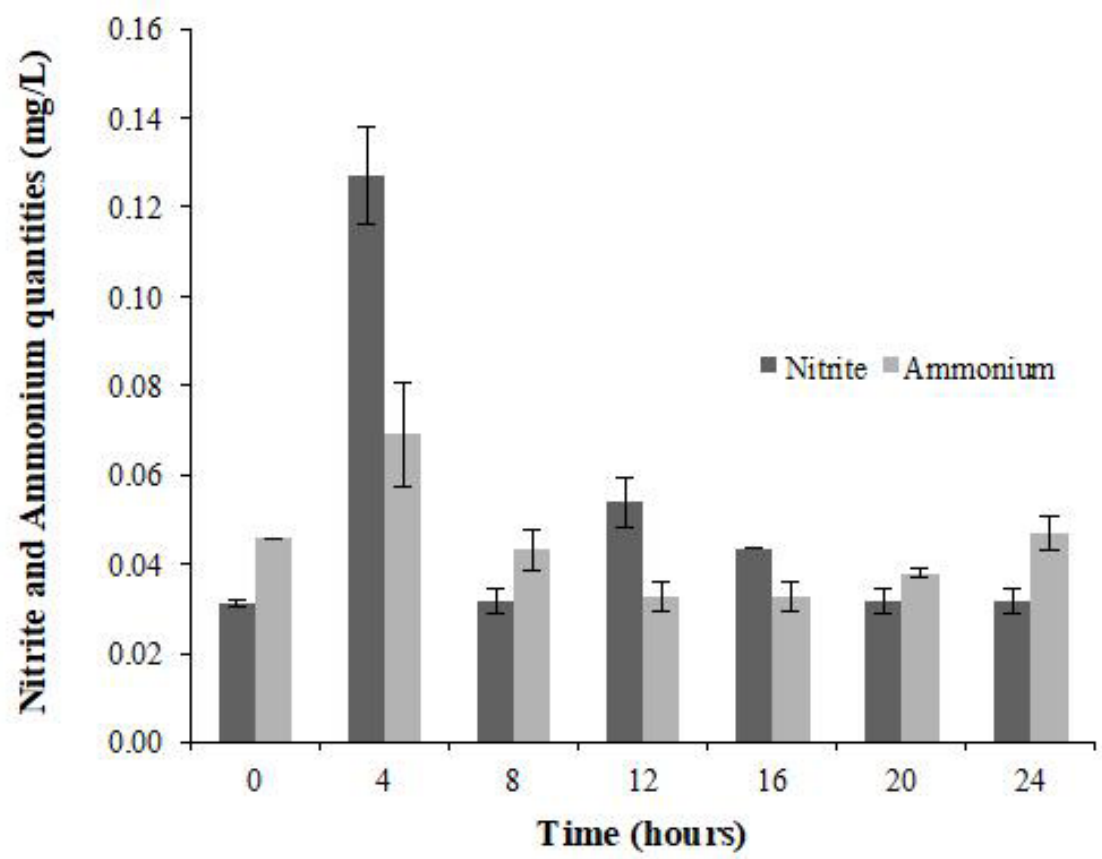

Figure 4. Amounts of nitrite and ammonium ions released during biological degradation period of TNT by the consortium.

able to resist the presence of TNT. Furthermore, the bacterial enzyme activity of the strains may be catalyzed with TNT as reported by previous studies [46]. The isolated strains were examined to determine their capacities to remove TNT. Three bacteria isolates were selected for further studies according to their TNT degradation rate and growth abilities in the presence of TNT as sole nitrogen source. The selected strains were identified with Gram-staining and 16S rRNA sequence analysis. All three selected bacteria were Gram-negative and rod-shaped bacterium. According to $16 \mathrm{~S}$ rRNA sequence analysis, SC1 K1 showed $99 \%$ homology with Klebsiella pneumoniae, SC1 K4 showed 99\% homology with Raoultella planticola, and SC1 K5 had 99\% similarity with Pseudomonas putida. Degradation of TNT with Klebsiella sp. also reported by several previous studies $[44,47,48]$. However, the TNT degradation ratio of Klebsiella pneumoniae $\mathrm{SC} 1 \mathrm{~K} 1$ was higher compared to the previous TNT degradation works with Klebsiella sp. or Klebsiella pneumonia. Degradation of TNT with Pseudomonas sp. or Pseudomonas putida also studied by many researchers and the results are reported in a few studies $[1,32,43]$. Biological transformation of TNT with Raoultella terrigena was studied by Claus et al. [49], but there has been no study on degradation of TNT with Raoultella planticola in the literature. This study is the first report on TNT degradation with Raoultella planticola.

The isolated strains were incubated in medium containing $100 \mathrm{ppm}$ TNT as sole nitrogen source and during the degradation period, the bacterial growth was proportional with degradation rate of TNT. SC1 K1, SC1 K4 and SC1 K5 isolates successfully removed between $84-95 \%$ of the initial amount of TNT within 24-hour incubation time in the basal salt medium. Then, we constructed the bacterial consortium from these selected strains to examine TNT degradation. The consortium successfully removed $97.2 \%$ of the initial TNT from the culture medium within 4 hours and the developed consortium was capable of degrading all of initial TNT in the culture medium within 24hour incubation at $30{ }^{\circ} \mathrm{C}$ and $\mathrm{pH}$ 7. Degradation experiments showed that the consortium had superior potential to degrade TNT compared to the individual bacterial strains. The reason for faster and effective degradation of TNT by the consortium might be related with the combined activities and interactions of the selected strains.

In the consortium, TNT was used as nitrogen source to grow and successful transformation of TNT into 2-ADNT, 4-ADNT and an unknown metabolite were detected by HPLC analyses during 
the degradation period. Formations of 2-ADNT and 4-ADNT were reported in previous studies $[10,16,33,40,42,43,49]$ and accumulation of unknown metabolites during TNT degradation has been also reported in the literature $[33,49]$ and these results are compatible with the previous studies. Since mutagenicity of TNT is higher than 2-ADNT and 4-ADNT and the solubility of these compounds is lower than TNT, the conversion of TNT to these compounds is favorable [50]. During degradation process, accretion of 4-ADNT in the culture of the consortium was higher than 2-ADNT and it was expected because the nitro group in the para position is more readily reducible than those in the ortho positions of TNT [51]. By HPLC analysis, 4-ADNT and 2-ADNT were identified as degradation products in the supernatants of the culture because they were water-soluble in the culture medium. Probably, Claus et al. [49] reported that the rest of degradation metabolites (azoxy-dimers) remained as insoluble material in the cell extracts.

The liberation of nitrite ions from TNT and the liberation of ammonium from hydroxylaminodinitrotoluene transformation products are indicators for microbial degradation of TNT [52]. The consortium released $\mathrm{NO}_{2}^{-}$and $\mathrm{NH}_{4}{ }^{+}$during the degradation process and the nitrite ion concentration reached maximum after $4 \mathrm{~h}$. In several studies, nitrite and ammonium accumulations were also detected during TNT degradation by different microorganisms and these results support the results of the present study $[16,33,42,43]$. The accumulation of nitrite ions during the degradation of TNT showed that the consortium could degrade TNT by direct reduction of the aromatic ring to give Meisenheimer complexes as reported in previous studies $[10,33]$. In the supernatants, the nitrite concentration increased slightly after 4-h incubation time, but the accumulation of denitrated transformation metabolites of TNT in the supernatants of isolate was not observed as previously reported by Claus et al. [49].

The microbial degradation of organic compounds is more effective when the microorganisms used for degradation are preselected as stated by Sarkar et al. [53] Since the isolates used for developing the bacterial consortium were obtained from TNT contaminated environment and preselected, the consortium could use TNT instantly after it was inoculated into TNT-containing environment as stated previously by Kumagai et al. [54] and Gumuscu and Tekinay [16]. After 4-hour of incubation of the isolates into the degradation medium containing TNT, nitrite release reached maximum level and the remaining amount of TNT in the culture medium became 2.8 $\mathrm{mg} \mathrm{L}^{-1}$ as the bacterial biomass increased. These results indicated that the constructed consortium could effectively destroyed TNT in the first four hours of incubation.

\section{CONCLUSION}

The developed consortium converted TNT to degradation products 2-ADNT, 4-ADNT and an unknown metabolite that were determined by HPLC. All of these results showed that the strains had potential to be used for bioremediation and restoration of TNT-contaminated sites as individual or in a bacterial consortium and the results of the study highlight the application of the developed consortium as bioremediation agent of TNTcontaminated sites. Further studies are required to assess the potential of the consortium to degrade TNT in situ bioremediation application.

\section{Acknowledgments}

The study was financially supported by Kırıkkale University under the project no 2014/62. The authors would like to thank the Republic of Turkey, Ministry of Science, Industry and Technology (TÜBITAK) for supporting to Zehra Gün Gök in her master program.

\section{References}

1. K. Ayoub, E.D. van Hullebusch, M. Cassir, A. Bermond, Application of advanced oxidation processes for TNT removal: A review, J. Hazard. Mater., 178 (2010) 10-28.

2. R. Boopathy, Bioremediation of explosives contaminated soil, Int. Biodeterior. Biodegrad., 46 (2000) 29-36.

3. R. Chakraborty, S.M.O. Connor, E. Chan, J.D. Coates, Anaerobic Degradation of Benzene, Toluene, Ethylbenzene and Xylene Compounds by Dechloromonas Strain RCB, Appl. Environ. Microbiol., 71 (2005) 8649-8655.

4. D.H. Buckley, V. Huangyutitham, S.F. Hsu, T.A. Nelson, Stable isotope probing with $15 \mathrm{~N}$ achieved by disentangling the effects of genome $\mathrm{G}+\mathrm{C}$ content and isotope enrichment on DNA density, Appl. Environ. Microbiol., 73 (2007) 3189-3195. 
5. A. Esteve-Núñez, A. Caballero, J.L. Ramos, Biological degradation of 2,4,6-trinitrotoluene, Microbiol. Mol. Biol. Rev., 65 (2001) 335-352.

6. E.M. Gallagher, Anaerobic Degradation of 2,4,6 Trinitrotoluene (TNT): Molecular Analysis of Active Degraders and Metabolic, PhD Thesis, The State University of New Jersey, New Jersey (2010) 1-127.

7. L. Haselhorst, Bioremediation of 2,4,6-Trinitrotoluene (TNT) at munitions sites, Restor. Reclam. Rev., 4 (1999) 1-9.

8. C. Park, T.H. Kim, S. Kim, S.W. Kim, J. Lee, S.H.S. Kim, Optimization for biodegradation of 2,4,6-trinitrotoluene (TNT) by Pseudomonas putida J. Biosci. Bioeng., 95 (2003) 567-571.

9. B.K. Robertson, P.K. Jjemba, Enhanced bioavailability of sorbed 2,4,6-trinitrotoluene (TNT) by a bacterial consortium. Chemosph., 58 (2005) 263-270.

10. H.A. Mercimek, S. Dincer, G. Guzeldag, A. Ozsavli, F. Matyar, A. Arkut, F. Kayis, S.M. Ozdenefe, Degradation of 2,4,6-trinitrotoluene by $P$. aeruginosa and characterization of some metabolites, Brazilia. J. Microbiol., 46 (2015) 103-111.

11. D. Kalderis, S.B. Hawthorne, A.A. Clifford, E. Gidarakos, Interaction of soil, water and TNT during degradation of TNT on contaminated soil using subcritical water, J. Hazard. Mater., 159 (2008) 329-334.

12. K.B. Lee, M.B. Gu, S.H. Moon, In situ generation of hydrogen peroxide and its use for enzymatic degradation of 2,4,6-trinitrotoluene, J. Chem. Technol. Biotechnol., 76 (2001) 811-819.

13. S.Y. Oh, H.S. Yoon, T.Y. Jeong, S.D. Kim, Evaluation of remediation processes for explosive-contaminated soils: Kinetics and Microtox ${ }^{\circledR}$ bioassay, J. Chem. Technol. Biotechnol., 91 (2016) 928-937.

14. S.B. Funk, D.L. Crawford, R.L. Crawford, Bioremediation of nitroaromatic compounds, In: D.L. Crawford, R.L. Crawford (eds.) Bioremediation Princ. Appl. Cambridge University Press, Cambridge, 1996 195-205.

15. G.R. Chaudhry, Biological Degradation and Bioremediation of Toxic Chemicals, Dioscorides Press, Portland, 1994.

16. B. Gumuscu, T. Tekinay, Effective biodegradation of 2,4,6-trinitrotoluene using a novel bacterial strain isolated from TNT-contaminated soil, Int. Biodeterior. Biodegrad., 85 (2013) 35-41.

17. K. Panz, K. Miksch, Phytoremediation of explosives (TNT, RDX, HMX) by wild-type and transgenic plants J. Environ. Manage., 113 (2012) 85-92.

18. R.E. Kirk, P.F. Othmer, Encyclopedia of Chemical Technology, John Wiley \& Sons, New York, 1993.

19. J.D. Rodgers, N.J. Bunce, Treatment methods for the remediation of nitroaromatic explosives, Water Res. 35 (2001) 2101-2111.

20. H. Claus, Microbial Degradation of 2,4,6Trinitrotoluene In Vitro and in Natural Environments, In: S. Singh (eds.) Biol. Remediat. Explos. Residues, Springer International Publishing, Switzerland, (2014) 15-38.

21. N.C. Bruce, Microbial Degradation of Energetic Compounds, J. Chem. Technol. Biotechnol., 11 (1996) 362-364.

22. R. Boopathy, J. Manning, C.F. Kulpa, Biotransformation of explosives by anaerobic consortia in liquid culture and in soil slurry, Int. Biodeterior. Biodegradation., 41 (1998) 67-74.
23. T.C. Schmidt, K. Steinbach, E. von Löw, G. Stork, Highly polar metabolites of nitroaromatic compounds in ammunition wastewater, Chemosph., 37 (1998) 1079-1090.

24. W.J. Wujcik, W.L. Lowe, P.J. Marks, W.E. Sisk, Granular activated carbon pilot treatment studies for explosives removal from contaminated groundwater, Environ. Prog., 11 (1992) 178-189.

25. M., Erkelens, E.M. Adetutu, M. Taha, L. TudararoAherobo, J. Antiabong, A. Provatas, A.S. Ball, Sustainable remediation-The application of bioremediated soil for use in the degradation of TNT chips, J. Environ. Manage., 110 (2012) 69-76.

26. M. Kulkarni, A. Chaudhari, Microbial remediation of nitro-aromatic compounds: An overview, J. Environ. Manage., 85 (2007) 496-512.

27. J.W. Kang, Removing environmental organic pollutants with bioremediation and phytoremediation, Biotechnol. Lett., 36 (2014) 1129-1139.

28. P. Bayman, G.V. Radkar, Transformation and tolerance of TNT (2,4,6-trinitrotoluene) by fungi. Int. Biodeterior. Biodegrad., 39 (1997) 45-53.

29. K.L. Sublette, E.V. Ganapathy, S. Schwartz, Degradation of munition wastes by Phanerochaete chrysosporium. Appl. Biochem. Biotechnol., 34-55 (1992) 709-723.

30. E.L. Rylott, N.C. Bruce, Plants disarm soil: engineering plants for the phytoremediation of explosives, Trends. Biotechnol., 27 (2009) 73-81.

31. M.M. Ederer, T.A. Lewis, R.L. Crawford, 2,4,6-Trinitrotoluene (TNT) transformation by clostridia isolated from a munition-fed bioreactor: comparison with non-adapted bacteria, J. Ind. Microbiol. Biotechnol., 18 (1997) 82-88.

32. A. Esteve-nuñez, G. Lucchesi, B. Philipp, B. Schink, J.L. Ramos, Respiration of 2,4,6-Trinitrotoluene by Pseudomonas sp. Strain JLR11, J. Bacteriol., 182 (2000) 1352-1355.

33. L. Zou, D. Lu, Z. Liu, Pathways for Degrading TNT by Thu-Z: A Pantoea sp. Strain, Appl. Biochem. Biotechnol., 168 (2012) 1976-1988.

34. J.C. Spain, J.B. Hughes, H.J. Knackmuss, Biodegradation of Nitroaromatic Compounds and Explosives, Lewis Publishing, Florida, 2000.

35. J.A. Field, E. de Jong, G. Feijoo-Costa, J.A.M. de Bont, Screening for ligninolytic fungi applicable to the biodegradation of xenobiotics, Trends Biotechnol., 11 (1993) 44-49.

36. O. Drzyzga, D. Bruns-Nagel, T. Gorontzy, K.H. Blotevogel, D. Gemsa, E. von Löw, Mass balance studies with 14C-labeled 2,4,6-trinitrotoluene (TNT) mediated by an Anaerobic Desulfovibrio species and an Aerobic Serratia species, Curr. Microbiol., 37 (1998) 380-386.

37. M.I. Khan, J. Lee, J. Park, A toxicological review on potential microbial degradation intermediates of 2,4,6-trinitrotoluene, and its implications in bioremediation, KSCE J. Civ. Eng., 17 (2013) 1223-1231.

38. A. Üzer, E. Erça, R. Apak, Selective colorimetric determination of TNT partitioned between an alkaline solution and a strongly basic Dowex 1-X8 anion exchanger, Forensic Sci. Int., 174 (2008) 239-243.

39. D. Claus D, A standardized Gram staining procedure, World J. Microbiol. Biotechnol., 8 (1992) 451-452.

40. S. Hannah Elizabeth, A. Panneer Selvam, Pseudomonas aeruginosa SP TUHP1 isolated from TNT-polluted soils in thevellore district. Int. J. Pharm. Pharm. Sci., 6 (2014) 267-271. 
41. B.K. Shanmugam, S. Mahadevan, Metabolism and biotransformation of azo dye by bacterial consortium studied in a bioreaction calorimeter, Bioresour. Technol., 196 (2015) 500-508.

42. A.G. Rahal, A.M. Lobna, Degradation of 2,4,6-Trinitrotoluene (TNT) by Soil Bacteria Isolated From TNT Contaminated Soil, Aust. J. Basic. Appl. Sci., 5 (2011) 8-17.

43. H.A. Mercimek, S. Dincer, G. Guzeldag, A. Ozsavli, F. Matyar, Aerobic Biodegradation of 2,4,6-Trinitrotoluene (TNT) by Bacillus cereus isolated from Contaminated Soil, Microb. Ecol., 66 (2013) 512521.

44. G. Litake, S. Joshi, V. Ghole, TNT biotransformation potential of the clinical isolate of Salmonella typhimurium-potential ecological implications, Indian. J. Occup. Environ. Med., 9 (2005) 29-34.

45. M.E. Fuller, J.F. Manning, Aerobic Gram-positive and Gram-negative bacteria exhibit differential sensitivity to and transformation of 2,4,6-trinitrotoluene (TNT), Curr. Microbiol., 35 (1997) 77-83.

46. O. Muter, K. Potapova, B. Limane, K. Sproge, I. Jakobsone, G. Cepurnieks, V. Bartkevics, The role of nutrients in the biodegradation of 2,4,6-trinitrotoluene in liquid and soil, J. Environ. Manage., 98 (2012) 51-55.

47. H. Kim, G.N. Bennett, H. Song, Degradation of 2,4,6-trinitrotoluene by Klebsiella sp . isolated from activated sludge, Biotechnol. Lett., 24 (2002) 20232028.
48. J.H. Shin, H.G. Song, Nitroreductase II involved in 2,4,6-trinitrotoluene degradation: Purification and characterization from Klebsiella sp. cl, J. Microbiol., 47 (2009) 536-541.

49. H. Claus, T. Bausinger, I. Lehmler, N. Perret, G. Fels, U. Dehner, J. Preuss, H. König, Transformation of 2,4,6-trinitrotoluene (TNT) by Raoultella terrigena, Biodeg., 18 (2007) 27-35

50. T. Maeda, K. Kadokami, H.I. Ogawa, Isolated from TNTPolluted Soils in the Yamada Green Zone, Kitakyushu, Japan., J. Environ. Biotechnol., 6 (2006) 33-39.

51. S.E. Barrows, C.J. Cramer, D.G. Truhlar, M.S. Elovits, E.J. Weber, Factors controlling regioselectivity in the reduction of polynitraromatics in aqueous solution, Environ, Sci. Technol., 30 (1996) 3028-3038.

52. B. Stenuit, S.N. Agathos, Rapid and unbiased colorimetric quantification of nitrite and ammonium ions released from 2,4,6-trinitrotoluene during biodegradation studies: Eliminating interferences, Int. Biodeterior. Biodegrad., 63 (2009) 116-122.

53. P. Sarkar, A.R. Rai, S. Ghosh, Degradation of aromatic petroleum hydrocarbons (BTEX) by a solvent tolerant bacterial consortium, J. Urban Environ. Eng., 7 (2013) 274-279.

54. Y. Kumagai, T. Wakayama, S. Li, A. Shinohara, A. Iwamatsu, G. Sun, N. Shimojo, Crystallin catalyzes the reductive activation of $2,4,6$ - trinitrotoluene to generate reactive oxygen species: A proposed mechanism for the induction of cataracts, FEBS Lett., 478 (2000) 295-298. 